\title{
Evaluation of the synergistic effect of danazol and radiation exposure on some biochemical functions in female albino rats.
}

\author{
Ramadan, F. L. \\ Radiation Biology Dep., National Center for Radiation Research and Technology (NCRRT), \\ Atomic Energy Authority (AEA), Egypt.
}

\begin{abstract}
Background: Radiation generates a variety of free radicals during the exposure of biological tissues through radiolysis of water. These free radicals are highly reactive and cause oxidative damage to biological molecules. The present study was carried out to investigate the synergestic effect of danazol and radiation exposure on certain functional disorders in female rats.

Material and methods: Mature female rats weighing about $120-150 \mathrm{~g}$ were divided into four groups. Group 1: control animals, group 2: animals orally administrated with danazol at a daily dose of $1.8 \mathrm{mg} / 100 \mathrm{~g} \mathrm{~b} . \mathrm{wt} / \mathrm{day}$ for four weeks., group 3: animals exposed to whole body gamma irradiation ( $5 \mathrm{~Gy}$ ), group 4: animals orally administrated with danazol two weeks before and two weeks after irradiation.

Results : Blood and liver samples were obtained two week post irradiation. Erythrocyte counts, haemoglobin concentration $(\mathrm{Hb})$, hamatocrite percentage $(\mathrm{Ht})$ and leucoyte counts (WBc's) were determined in blood. Total cholesterol (TC), triglycerides (TG), high density lipoprotein-cholesterol (HDL-c), low density lipoprotein-cholesterol (LDL-c), glucose as well as gamma glutamyle transferase $(\gamma-\mathrm{GT})$, transmaminase aspartat (AST), alanine (ALT) and estradiol serum hormone level were assessed. Peroxidative hepatic damage was investigated by assessing thiobarbituric acid reactive substance (TBARS) and total protein content in liver tissues. The data obtained revealed that exposure of rats to gamma radiation and / or danazol treatment or dual treatment caused a significant increase in ALT, AST, glucose, $\gamma$-GT, TC, TG, LDL-c and liver TABRS. While a significant decrease were recorded in RBc's Hb, Wbc's and HT.

On the other hand, serum HDL, estradiol and liver total protein in group treated with danazol declined compared to control group.

Conclusion: The results are of great importance from the stand point of radiation protection and drug safety.
\end{abstract}

\section{Introduction}

Ionizing radiation has been considered a source of naturally occurring physical damage to living organisms. At present, various man-mad therapeutic diagnostic or occupational sources of exposure to ionizing radiation are of far greater importance (Leadon, 1996). Radiation interacts with matter by direct and indirect processes to form ion pairs, some of which may be free radicals that lead to molecular damage translated to biochemical damage that may be then amplified and expressed as biological injury (Abou-Safi et al., 2005).
Danazol (DA-Na-Zole) is a synthetic steroid derived from 17-alpha ethinvltestosterone and it is used for curing number of different medical problems (Cai, et al., 1999). These included pain or infertility due to endometriosis and hereditary angioedema which causes swelling of sexual organs (Momeda, 2001). Its effectiveness is due to a reversible hypoestrogenic and hyperandrogenic state which lead to atrophy of the ectopic endometrial tissues (Tamaya, 2001). Radiation therapy is widely used because these is often no other 
choice for treatment endometriosis in infertility female. Revelance, the steadily are gowing number of female workers integrating their activities with such kind of radiation exposure and / or therapy.

In this respect, our study was carried out to study the synergistic effect of danazol and radiation exposure induced certain functional disorders in female albino rats.

\section{Material and Methods}

Mature female albino rats weighing $120-150 \mathrm{~g}$ were obtained from the animal farm of the Egyptian Organization for Vaccine and Biological products. Rate were housed in cages and maintained under standard condition of ventilation, temperature and humidity. Food and water were available ad-libitum.

\section{Radiation facility:}

Irradiation was performed by Cesium137 biological irradiation Gamma Cell-40 belonging to the NCRRT, Nase City, Egypt. Irradiation dose (5Gy) was applied as a shot dose at a dose rate of $1 \mathrm{~Gy} / 1.2 \mathrm{~min}$.

\section{Material:}

Danazol was purchased from SANDh1-Syinthelabo. Canada. It was dissolved in saline solution and orally administrated to rats at a dose of 1.8 $\mathrm{mg} / 100 \mathrm{~kg} \mathrm{b.wt/day} \mathrm{for} \mathrm{four} \mathrm{weeks.}$

\section{Experimental design:}

Animals were divided into 4 groups each of 5 rats:

1-Control group: Animals did not receive any treatment.

2-Danazol group: Animal orally administrated with danazol at a dose of $1.8 \mathrm{mg} / 100 \mathrm{~g}$ b.wt/day all over the experiment (four weeks).

3-Irradiated group: Animals irradiated at a dose of $5 \mathrm{~Gy}$.

4-Danazol and irradiated group: Animals treated with danazol two week pre and post irradiation (5 Gy).

\section{Biochemical Studies}

Five rats from each group were anaesthetized with ether and blood collected by heart puncture. Part of the blood was collected on EDTA for assay of $\mathrm{RBc}, \mathrm{s} \mathrm{Ht}$ and $\mathrm{WBc}, \mathrm{s}$ Dacie and Lewis (1991), blood haemoglobin was assayed as cyanmethaemoglobin using Spectrum Diagnostic kit according to Teitz, (1994). The rest of blood was centrifuged to separate serum to determine glucose level according to Trinder, (1969) using Scico diagnosis kit. Aminotransaminases activity levels were determined as described by Reitman and Frankel (1957) by kit of

plasmate laboratory LTd. Activity level of gamma glutamy transferase $(\gamma-\mathrm{GT})$ was measured colorimetrically according to the procedure of Szasz and Persijn (1974). Also, estradiol was determined by using Radioimmunoassay RIA technique (Diagnostic products corporation, Los Angeles, USA). Total cholesterol, high density lipoprotein cholesterol, low density lipoprotein cholesterol and triaglycrides were assayed in serum according to the method of Allan et al., (1974), Demacer et al., (1980), Friedewald et al. (1972) and Fossati and Prencipe (1982) respectively. Liver were excised and weighed then homogenized to determine total protein according to Lowry et al. (1951). Lipid peroxidation in liver tissue was ascertained by the formation of TBARS and measured as described by Yoshioka et al. (1979). Statistical analysis of data were performed using student t-test (Snedector and Cochron 1989).

\section{Results}

In the present study, experimental animals received danazol for 4 weeks at a dose equivalent to $1.8 \mathrm{mg} / 100 \mathrm{~g} \mathrm{~b}$.wt/day and / or exposed to gamma radiation (5 Gy) exerted a significant decrease in $\mathrm{RBc}, \mathrm{s} \mathrm{Hb}$, $\mathrm{WBc}, \mathrm{s} \mathrm{Ht}$ and HDL-c $(\mathrm{P} \leq 0.001)$ as compared to control group table (1 and 2). Table (3) indicated that whole body gamma irradiation (5 Gy) induced a significant increase in serum estradiol levels whereas treatment with danazol induced a significant decrease in the serum estradiol $(\mathrm{P}<0.001)$ as compared with control. Meanwhile, the tested treatment combination with danazol and radiation exhibited a tendency to decrease serum 
estradiol as compared to irradiated group. On the contrary, danazol administration and / or exposure to gamma radiation showed a significant elevation in serum TC, TG, LDL-c, glucose level, AST, ALT and $\gamma$-GT activity $(\mathrm{P}<0.001)$ in comparison with those of control group (table 2, 3). Data presented in table (4) showed a significant decline in total protein $(\mathrm{P}<0.001)$ parralled with a significant elevation of TBARS in experimental groups when compared to with control group.

Table (1): Effect of danazol administration to irradiated female rats on $\mathrm{RBc}\left(10^{6} / \mathrm{mm}^{3}\right), \mathrm{Hb}^{\circ}$ (g/dI), WBc's $\left(10^{3} / \mathrm{mm}^{3}\right)$ and HT (\%).

\begin{tabular}{|c|c|c|c|c|}
\hline $\begin{array}{l}\text { Parameter } \\
\text { Groups }\end{array}$ & RBc,s $\left(10^{6} / \mathrm{mm}^{3}\right)$ & Hb (g/dI) & WBc,s $\left(10^{3} / \mathrm{mm}^{3}\right)$ & HT (\%). \\
\hline Control & $5.644 \pm 0.241$ & $12.56 \pm 0.903$ & $6.17 \pm 0.324$ & $34.43 \pm 0.673$ \\
\hline Danazol & $3.560 \pm 0.377^{* * * *}$ & $9.00 \pm 0.631^{* *}$ & $4.06 \pm 0.172^{* * * *}$ & $30.04 \pm 0.696^{* * * *}$ \\
\hline$\gamma$-irradiation & $3.062 \pm 0.343^{* * *}$ & $8.06 \pm 0.617^{* * * *}$ & $3.36 \pm 0.192^{* * * *}$ & $29.86 \pm 0.399^{* * *}$ \\
\hline Danazol $+\gamma$-radiation & $2.928 \pm 0.146^{* * * *}$ & $7.36 \pm 0.640^{* * *}$ & $2.95 \pm 0.212^{* * *}$ & $27.298 \pm 0.645^{* * *}$ \\
\hline
\end{tabular}

Each value represents the mean of 5 observations \pm S.E.

$*, * *, * * *$ are the significant difference when compared with the corresponding value of control rats at $\mathrm{P}<0.05, \mathrm{P}<0.01, \mathrm{P}<0.001$.

Table (2): Effect of danazol administration to irradiated female rats on serum of (TC),(TG), HDLC and LDL-C (mg/dI).

\begin{tabular}{|l|l|l|l|l|}
\hline \multicolumn{1}{|c|}{ Parameter } & \multicolumn{1}{c|}{$\begin{array}{c}\text { TC } \\
\text { Groups }\end{array}$} & $\begin{array}{c}\text { TG } \\
(\mathbf{m g} / \mathbf{d I})\end{array}$ & $\begin{array}{c}\text { HDL-c } \\
(\mathbf{m g} / \mathbf{d I})\end{array}$ & $\begin{array}{c}\text { LDL-c } \\
(\mathbf{m g} / \mathbf{d I})\end{array}$ \\
\hline Control & $76.800 \pm 3.513$ & $82.800 \pm 6.127$ & $44.308 \pm 0.489$ & $30.088 \pm 0.035$ \\
\hline Danazol & $98.801 \pm 0.583^{* * *}$ & $106.300 \pm 6.066^{* * *}$ & $41.628 \pm 0.417^{* * * *}$ & $42.056 \pm 1.105^{* * *}$ \\
\hline $\boldsymbol{\gamma}$-irradiation & $116.801 \pm 5.314^{* * * *}$ & $135.400 \pm 9.389^{* * * *}$ & $36.638 \pm 1.379^{* * * *}$ & $46.916 \pm 1.164^{* * *}$ \\
\hline Danazol $+\boldsymbol{\gamma}$-radiation & $146.5 \pm 3.449^{* * * *}$ & $151.600 \pm 8.280^{* * * *}$ & $32.860 \pm 1.287^{* * * *}$ & $51.07 \pm 1.125^{* * *}$ \\
\hline
\end{tabular}

Table (3): Effect of danazol administration to irradiated female rats on serum glucose, AST, ALT, activity of $\gamma$-GT and estradiol level.

\begin{tabular}{|c|c|c|c|c|c|}
\hline $\begin{array}{l}\text { Parameter } \\
\text { Groups }\end{array}$ & $\begin{array}{l}\text { Glucose } \\
\text { (g/dI) }\end{array}$ & $\begin{array}{c}\text { AST } \\
(\mathbf{U} / \mathbf{m l})\end{array}$ & $\begin{array}{l}\mathbf{A L T} \\
(\mathbf{u} / \mathbf{m l}\end{array}$ & $\begin{array}{l}\gamma \text {-GT } \\
(\mathbf{U} / \mathbf{L})\end{array}$ & $\begin{array}{l}\text { Estradial } \\
\text { ( P g/ml) }\end{array}$ \\
\hline Control & $106.28 \pm 3.512$ & $63.88 \pm 0.671$ & $31.58 \pm 0.565$ & $20.270 \pm 0.765$ & $19.198 \pm 0.058$ \\
\hline Danazol & $139.11 \pm 8.429 * *$ & $69.37 \pm 0.666 * * *$ & $37.38 \pm 0.704 * * *$ & $29.648 \pm 1.284 * * *$ & $16.450 \pm 0.182 * * *$ \\
\hline$\gamma$-irradiation & $188.88 \pm 3.187 * * *$ & $71.22 \pm 0.665 * * *$ & $39.65 \pm 0.692 * * *$ & $46.270 \pm 1.753^{* * *}$ & $42.560 \pm 0.510 * * *$ \\
\hline $\begin{array}{l}\text { Danazol }+\gamma- \\
\text { radiation }\end{array}$ & $192.49 \pm 4.045 * * *$ & $75.82 \pm 0.652 * * *$ & $41.76 \pm 0.559 * * *$ & $49.710 \pm 0.271 * * *$ & $30.530 \pm 0.268 * * *$ \\
\hline
\end{tabular}

Leganed as Table (1). 
Table (4): Effect of danazol administration to irradiated female rats on thiobarbituric acid reactive substance (TBARS), total protein content in liver tissue.

\begin{tabular}{|l|l|l|}
\hline Groups & \multicolumn{1}{|c|}{$\begin{array}{c}\text { TBARS } \\
\text { (m mol/g tissue) }\end{array}$} & \multicolumn{1}{c|}{$\begin{array}{c}\text { Total protein } \\
\text { (g/g tissue) }\end{array}$} \\
\hline Control & $371 \pm 21.51$ & $0.51 \pm 0.020$ \\
\hline Danazol & $425 \pm 1.78^{* *}$ & $0.42 \pm 0.028^{* *}$ \\
\hline $\boldsymbol{\gamma}$-irradiation & $492 \pm 8.746^{* * *}$ & $0.40 \pm 0.017^{* * *}$ \\
\hline Danazol $+\boldsymbol{\gamma}$-radiation & $509 \pm 5.586^{* * *}$ & $0.36 \pm 0.016^{* * *}$ \\
\hline
\end{tabular}

Leganed as Table (1).

\section{Discussion}

In the present work, the results revealed that whole body gamma irradiation (5 Gy) or / and danazol administration at a dose of $1.8 \mathrm{mg} / 100 \mathrm{~g}$ b.wt/day produced haematological disorders. This was evident from the significant decrease in $\mathrm{RBc}, \mathrm{s}$ remarkable fall in $\mathrm{Hb}$ concentrations, significant drop in HT percentage and significant decrease in total WBC,s. The decrease in erythrocyte counts could be due to a drop in their production, increased destruction and / or haemorrhage due to the failure of thrombopoiesis. Our results are in complete harmony with those of (Hussein et al.. 2007, Ashry, 2003 and Lee and Ducoff 1994). Radiation damage of haemoglobin is considered as one of the most important mechanisms triggering radiation sickness (Kurbanov et al., 1995). The decrease in Hb content (HT \%) due to the radiation induced changes in erythrocyte membrane emphasizes the formation of free radicals. The effect of free radicals on erythrocyte membrane may contribute to the eventual leak of haemoglobin out of the cells (Hussein et al., 2007). Irradiation of rats caused retardation in incorporation of iron and decrease in haemoglobin binding to erythrocyte membrane. This finding agree with that observed by Tanikawa et al. (1990).

Leucocytes are highly radiosensitive to radiation and are considered as a sensitive biological indicator for the diagnosis of radiation injures (Moss et al., 1979). In the present study, the reduction in total leucocytes count (leucopenia) after irradiation of animals could be attributed to mitotic inhibition of the bone marrow precursors (Hassan et al., 1996). On the other hand, danazol caused impairment in immune system which may has resulted in a defect in the ability to remove debris in the perutoneum and lacke of serum-soluble human leukocyte antigen which lead to hemolytic anemia (Moen et al., 1984). The present results demonstrated that exposure of animals to gamma radiation and / or danazol treatment showed a significant elevation in serum cholesterol, triglycride, low density lipoprotein and a decrease in high density lipoprotein. These data are in accordance with previous results of Ragab and Ashry 2004, and Abou Safi et al., 2005 who observed that the elevation in serum lipid fractions might result from ionizing radiation ability to accelerate other pathways of cholesterol formation like increasing its rate of biosynthesis in the liver and other tissues, or destruction of cell membrane by radiation and also to disturbance LDL cholesterol recepetors, leading to hypercholesterolemia which affect particularly on polyunsaturated fatty acids and increase lipid peroxidation Kolomigseva, 1986 and Karbownik and Reiter 2000. On the other hand, danazol administration indicated that VLDL was catabolized and converted to LDL while the formation of HDL was impaired due to low activity of apoprotein A and B (Fukuda and Tamura 1987). The recorded consequently elevated level of triglycerides correlates previous finding of Osman, (1996) and Abou-Safi et al. (1999), who observed that after irradiation insulin level increased and synthesis of triglycerides was increased in both adipose tissues and liver which was accompanied by an acceleration of fatty acids mobilization from fat dopots to blood. 
Moreover, Ellefson and Caraway (1976) stated that hyperglyceridemia may be caused by metabolic disorder as a result of endocrine dysfunction and increased level of glucose. The recorded hyperglycemia in our results could be attributed to endocrine abnormalities induced by irradiation that promote the secretion of peptide which has relation to carbohydrate metabolism by increasing glyconeogenesis in liver (Darwish et al., 2007).

Results of the present investigation showed that irradiation (5 Gy) of female rats or treatment with danazol induced disturbance in the secretory activity of the ovaries. Such effect was manifested by the significant increase in serum estradiol level after exposure of rats to gamma radiation. These observation were similar to those described by Banetskay and Amvrosev (1995) who indicated that marked stimulation of the ovulation was detected at once after irradiation, which can be connected with changes of the hormonal balance in animal body and also increased number of atretic follicles as a result of production of free radicals which induce cellular changes (Hassan and Abou-Safi 1998). Therefore, the lower penetration of hormones in a tissue target leads to its accumulation in blood (Ramadan and Rezk 2004). The decrease in serum steroid hormones (estradiol) after treatment of rats with danazol could attributed to danazol effect on ovarian and anterior pituitary gland which lead to an increase in androgenic activity (Fedele et al., 1993 and Liu et al, 1998). Furthermore, Meldrum et al. (1983) observed that sex hormone binding globulin was markedly suppressed throughout danazol treatment resulting in elevation of testosterone and decrease esterogen level. Our results manifested a significant increase in ALT, AST and GGT activities after exposure of rats to gamma radiation or danazol administration. GGT activity is considered to be one of the best indicators of liver damage since it is embedded in the hepatocytes plasma membrane and the libration of this enzyme to sera levels damage to the cell and then injury of the liver, which lead to increase in lipid peroxides (Muriel et al., 1992 and Gharib, 2007). The present data further demonstrated a significant increase in serum transaminase activity in all experimental groups. This conclusion agree with that found by (Abdel-Gawad and Ahmed 2005). The increased levels of AST and ALT could be referred to the drastic dysfunction of the liver cells induced by radiation interaction with cellular membranes and also related to extensive breakdown of liver parenchyma (Kafafy 2000). However, the increase in TBARS might be explained on the basis that exposure of female rats to ionizing radiation increased the amount of free radicals in the body especially potent hydroxyl radicals $(\mathrm{OH})$ attack the polyunsaturated fatty acids in the phospholipids portion of cell membranes initiating the lipid peroxidation chain reaction (Darwish et al., 2007). Moreover, also danazol caused cytotoxicity for cell which causes elevation of lipid peroxidation (Stevenson et al., 2000). The registered decrease in total protein content of liver tissue could be similar to other findings of (Azab, 1996 and Abou Safi et al., 2005) who reported that radiation could induce variety of membrane changes including lipid peroxidation and amino acid damage in membrane proteins.

On the other hand, danazol treatment interfered with the function of liver which lead to severe anemia and it caused hepatic failure (Holt and Keller 1984). In addition, the treatment of animals with danazol was related to the decline in $\mathrm{Ca}^{++}$ion concentration which lead to decrease total protein (Kriplani et al., 1998).

According to the present results it could be concluded that radiation exposure or / danazol intake could exert a deleterious biological effect. Therefore, it is recommend that radiation occupational workers especially females have to be carful toward danazol intake.

\section{References}

1. Abdel Gawad I I and Ahmed A M (2005): Lipid peroxidation and electrolyte irradiated rats treated with caffeine. Egypt. J. Rad. Sci, Appl., 18 (1):6-12.

2. Abou-Safi $\mathbf{H} \mathbf{M}$, Ashry $\mathbf{O} \mathbf{M}$ and Kafafy Y A (2005): Effect of N-acetyl-L-cysteine and $\alpha$-tocopherol administration on endogenous antioxidant protection of liver 
DNA and RNA and plasma lipid profile in $\gamma$-irradiated rats. Egypt. J. Sci. Applc. Vol.18, No. 1 pp.81-96.

3. Abou-Safi $\mathbf{H}$ M, Hussein $A$ H and ElSayed N M (1999): Efficacy of vitamins A and / or E as antioxidants against serum glucose, liver glycogen and lipid discrepancy induced by gamma radiation during the estrus cycle of rats. Egypt. J. Rad. Sci. Applic. Vol. 12, No.2. pp. 1-146.

4. Allan R and Roxon J (1974): Metabolism by intestinal bacteria: The effect of bile salts on tartrazine azo reduction. Xenobiotica, 4: 637-647.

5. Ashry O (2003): Modulation of radiation induced toxicity by caffeine preinjection in female rats. Egypt. J. Rad. Sci. Applic., 16 (1): 1-11.

6. Azab K S M (1996): Response of certain biochemical parameters to whole body gamma irradiation in albino rats and synergistic effect of Pharmacological agent. Ph.D. Thesis, Faculty of Science of Alexandria Univ. Egypt.

7. Banetskay and Amvrosev (1995): Clinical and experimental study on the treatment of endometriosis with dan'e mixture. Zhonigguo Zhong Xi Yl 19 (3): 159-220.

8. Cai L, Shu Y and Xie H (1999): Clinical and experimental study on the treatment of endometriosis with dan a mixture. Zhongguo Zhong Xi Yi Jie the Za Zhi, 19 (3): 159-161.

9. Dacie $S$ T and Lewis $S$ M (1991): Practical haematology. $7^{\text {th }}$ ed. Churchill, Levingston. Medical Division of Longman Group. UK. LTd.

10. Darwish M M, Hussien E M and Haggag A M (2007): Possible role of licorice roots (glycyrrhiza glabra) as a natural radioprotector against oxidative damage in rats. Egypt. J. Rad. Sci. Applic., Vol, 20, No. (1): 95-108.

11. Demacer $\mathbf{P} \mathbf{N} \mathbf{M}$, Nasjanssen $\mathbf{H}$ E Hifmas A G M, Vant's Lear A and Jansen A P (1980): Measurement of high density lipoprotein cholesterol in serum comparison of sex isolation methods combined with enzymatic cholesterol analysis. Clin. Chem. 26 (13): 178-186.

12. Ellefson R D and Caraway W T (1976): Lipids and lipoproteins In: Fundamentals in clinical chemistry edated by Tietz, N. pp. 474-541.

13. Fedele, L,Marchini M,Bianchi $\mathbf{S}$ and Zanotti F (1993): Vaginal patterns during danazol and buserelin acetate therapy for endometriosis: Structural and Ultrastructural study. Fertil Steril; 59 (6): 1191-1196.
14. Fossati P and Prencipe L (1982): Serum triglyceride determined colourimetrically with an enzyme that produce hydrogen peroxide. Clin. Chem. 28, 2077.

15. Friedewald W T , Levy $\mathbf{R}$ I and Fredrickson D (1972): Estimation of concentration of low-density lipoprotein cholesterol in plasma without use of the preparative ultracentrifuge. Clin. Chem., 18 (6): 499.

16. Fukuda $Y$ and Tamura $S$ (1987): Effects of danazol on serum lipd and lipoprotein levels in patients with endometriosis. Nippon Sanka Fujinka Gakkai Zasshi., 39 (6): 980-986.

17. Gharib O A (2007): Does kombucha tea reduce the damage induced by radiation exposure. Egypt. J. Rad. Sci, Applic., Vol 20, 1, 141-157.

18. Hassan S, Abu-Gahadeer A and Osman S (1996): Vitamins B group and / or folic acid restoring the haematopoieic activity in irradiated rats. Egypt. J. Rad. Sci. Applic., 9 (1): 67-78.

19. Hassan S H and Abu-Safi H M (1998): Prophylatic and therapeutic role of combined treatment with vitamin A and B group for restoration of ovarian hormones level in irradiated rats. J. Egypt. Ger. Soc. Zool. Vol. 25 (A) 89-104.

20. Holt A P Sr and Keller D (1984): Danazol treatment increase serum enzyme levels. Fertil Steril; 41 (1): 70-74.

21. Hussien $\mathbf{E}$ M, Darwish $\mathbf{M} \mathbf{M}$ and Ali S E (2007): Prophylactic role of combined treatment with Coenzyme Q 10 and Vitamin $\mathrm{E}$ against radiation in male rats. Egypt. J. Rad. Sci. Applic., vol 20, 1. 181194.

22. Kafafy Y (2000): Protective effect of cytoeime and vitamin $\mathrm{E}$ on gamma irradiation injury in rats. Egypt. J. Rad. Sci. Applic., 13 (2): 17-25.

23. Karbownik $M$ and Reiter $R$ S (2000): Antioxidantative effects of melatonin in protection against cellular damage caused by ionizing radiation. Proc. Soc. Exp. Biol. Med. 225 (1): 9-16.

24. Kolomigtseva I K (1986): Activation of chelosterologensis under the effect of ionizing radiation mammalin body. Radiobiologiya, 26 (1): 3.

25. Kriplani A, Nath A, Takkar D and Maya, Kaul H L (1998): Biochemical hemodynamic and hematological changes during transcervical resection of the endometrium using $1.5 \%$ glycin as the irrigating solution. Eur, A. obstet. Gynecol. Repord Biol., 80 (1): 99-104.

26. Kurbanov F F, Mamedov T C, Abdullaev 


\section{Ramadan, F. L.}

Kh D and Manoilov S K (1995): A quantitative analysis of haemoglobin composition structure and properties under the action of radiation in vivo consutions. Rad. Biol. Radioecol., 35 (2): 200-210.

27. Leadon S A (1996): Repair of DNA damage produced by ionizing radiation. A mini review Seminars in radiation. Oncology, Univ. North Carolina, USA., 6 (4): 295-305.

28. Lee S W and Ducoff J S (1994): The effects of ionizing radiation on avian erythrocytes. Rad. Res., 137 (1): 104-110.

29. Liu, J.; Li, X. and Hu, X. (1998): Clinical observation on treatment of endometriosis by tonifying kidney and removing blood stasis. Suzhou Maternity and Infant health Institute 18 (3): 145-152.

30. Lowry O H, Rosebrough N I, Farr A L and Randall R J (1951): Protein measurement with folin phenol reagent. J. Biol. Chem.., 193, 265.

31. Meldrum D R, Paradridge W M, Rivier J, Vale $W$ and Judd $H$ L (1983): Hormonal effects of danazol and medical oophorectomy in endrometriosis. Obstet Gynecol. 62 (4): 480-485.

32. Moen M, Bratli A and Moen T (1984): Distribution of HLA antigens among patients with endometricosis. Acta obstet Gynecol Scand 123: 25-27.

33. Momoeda M (2001): Strategy of treatment for infertile women with endometriosis. Nippon Rinsho, 59 (1): 172-178.

34. Moss W, Brand $\mathbf{W}$ and Bellifara $\mathbf{H}$ (1979): In: The Hematopietic Tissue. $5^{\text {th }}$ ed. Rad. Com. Toronto-London, p 59.

35. Muriel P, Garciapina T, Perez-Alvarez V and Mourelle $M$ (1992): Silymarin protects against paracetamol-induced lipid peroxidation and liver damage. J. Appl. Toxicol., 12 (6): 439-448.

36. Osman S A A (1996): Melatonin beosting antioxidant capacity for effective radiation protection in albino rat. Egypt. J. Med. Sci., 17 (2): 281-295.
37. Ragab E A and Ashry O M (2004): Lipid and carbohydrate metabolism in rats. Egypt. J. Rad. Sci. Applic, Vol. 17, N (2) pp. 403-414.

38. Ramadan F L and Rezk R G (2004): Evening primrose oil attenuates certain radiation induced functional and structural disorders in female rats. The Egyptian J. of Hosp. Med. Vol., 16: 119-131.

39. Reitman S and Frankel S (1957): A colourimetric method for the determination of serum glutamic oxaloacetic and glutamic pyruvic transaminases. Am. J. Clin. Path, 28: 57-66.

40. Reitz N. (1994): Text Book of clinical Chemistry. 3nd ed., Saunders Company: 1997 and 521.

41. Snedecor G W and Cochron W G (1989): Statistical Methods, $8^{\text {th }}$ ed., Lowis state Univ. Press. Ames Lowa USA.

42. Stevenson A F, Xing X. and Kunstmann $P$ (2000): Study of growth the features and fertility effect after danzol / hormonal therapy. J. Exp. Biol., 33 (12): 1192-1200.

43. Szasz G, Persihn J P (1974): Alklin. Chem. Klin. Biochem, 12: 228, C. F. Pointe Scientific Inc., Lincoin Park, Muchigon, USA.

44. Tamaya T (2001): Danazol up to date aspect for endometriosis. Nippon Rinsho, 1 : 139-188.

45. Tanikawa S, Nose M, Aoki Y, Tsuneoka $K$ and Vara $N$ (1990): Effects of recombinant human granulocyte colonystimulating factor on the hematologic recovery and survival of irradiated mice. Blood, 76 (3): 445.

46. Trinder P (1969): Ann. Clin. Biochem. 6: $24 \mathrm{CF} /$ Biomerieux Comp. France.

47. Yoshioka T, Kawada K, Shimada T and Mori M (1979): Lipid peroxidation in maternal cord blood and protective mechanism against activated-oxygen toxicity in the blood. Am. J. Obstet. Gynecol., 135 (3): 372. 


\title{
تقييم التأثيرات المؤازرة للانزول والتعرض الإشعاعى على بعض الوظائف الحيوية ولية \\ في إناث الجرذان البيضاء
}

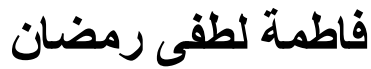

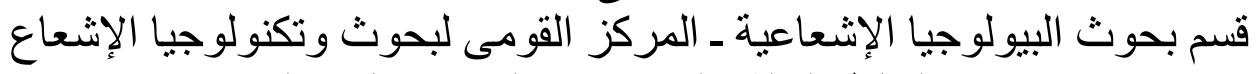 \\ هيئة الطاقة الذرية ـ جمهورية مصر العربية العربية
}

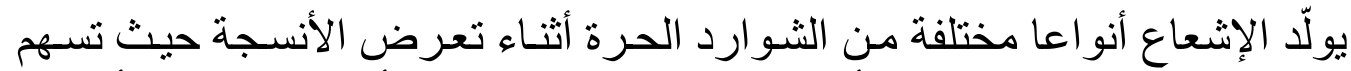

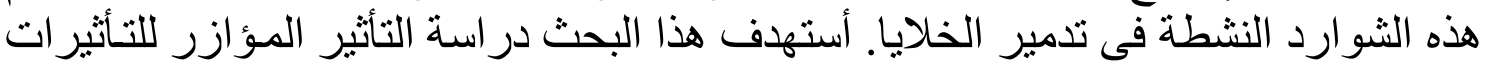

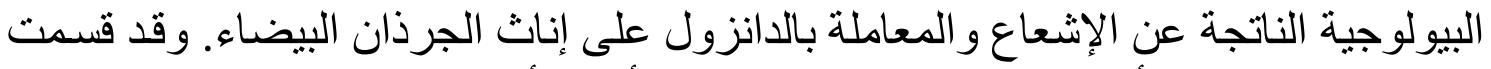

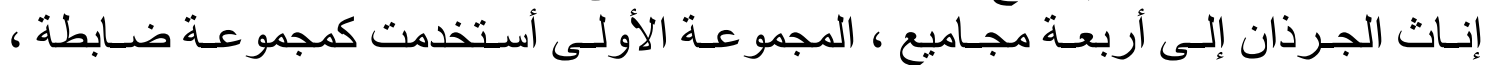

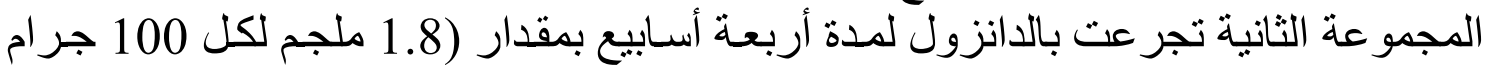

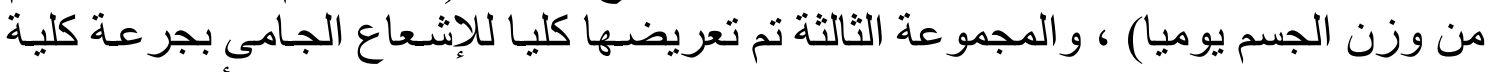

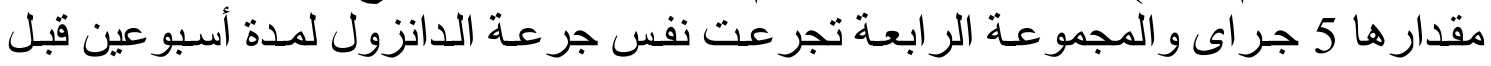

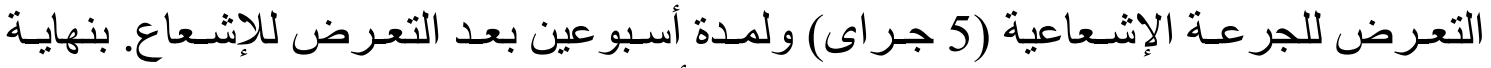

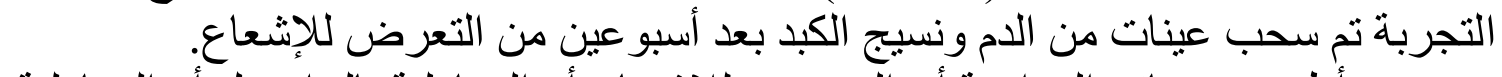

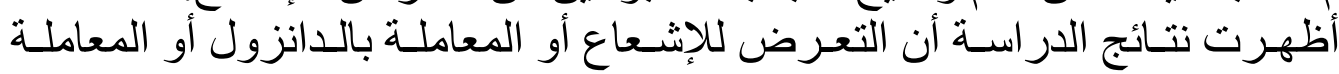

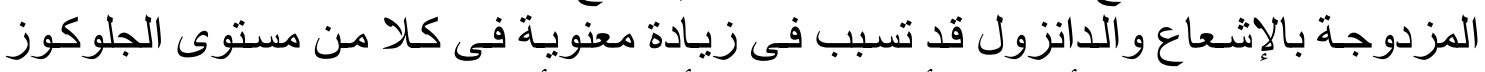

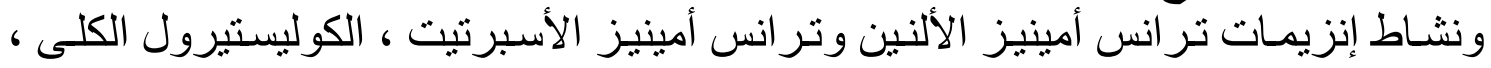

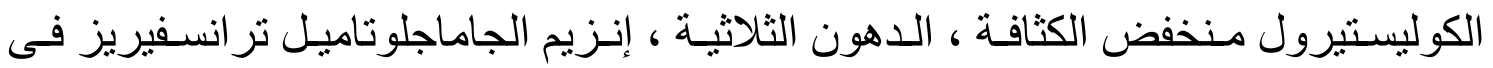

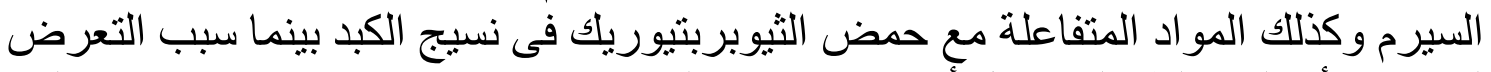

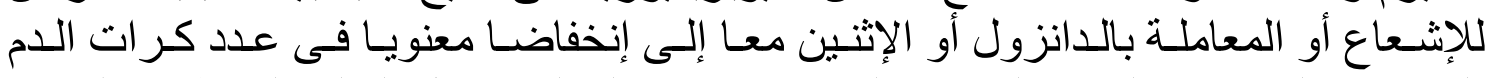

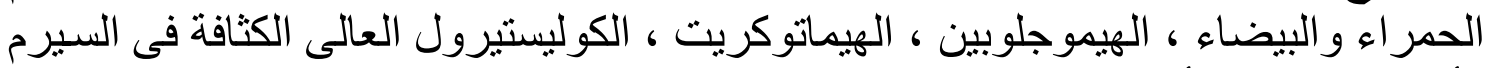

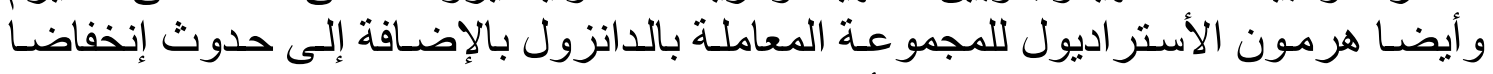

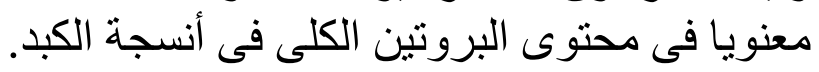

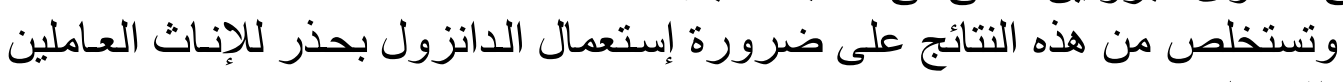
فى مجال الإشعاع. 